\title{
Tubular dysfunction in type I diabetes mellitus
}

\author{
M MILTÉNYI, A KÖRNER, T TULASSAY, AND A SZABÓ \\ First Department of Paediatrics, Semmelweis University Medical School, Budapest, Hungary
}

SUMmaRY Tubular function was investigated in patients with diabetic ketoacidosis and those

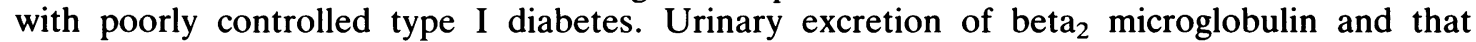
of certain enzymes: $\gamma$ glutamyltransferase, leucine aminopeptidase, and $\mathrm{N}$-acetyl- $\beta$-Dglucosaminidase activities were significantly raised during ketoacidosis in 11 patients compared with healthy controls. In 13 poorly controlled diabetics, tubular electrolyte transport was studied and a significant reduction in tubular phosphate and sodium reabsorption was found. Tubular dysfunction occurring during diabetic ketoacidosis and in poorly controlled diabetics may contribute to the development of diabetic nephropathy.

In an earlier study we found reversible tubular proteinuria in diabetic children during hyperglycaemic ketoacidosis. ${ }^{1}$ In the present study further aspects of tubular dysfunction were investigated.

\section{Patients}

Urinary excretion of beta $a_{2}$ microglobulin and of certain enzymes was investigated in three groups of patients:

(i) Eleven diabetics with ketoacidosis, aged mean (SD) $9.6(3.7)$ years, who had had diabetes for 1.4 $(1 \cdot 7)$ years. Six of the patients were newly diagnosed and five had been diabetic for less than five years. At the start of our investigation the blood glucose concentration for the entire group was mean (SD) $22 \cdot 2(8 \cdot 8) \mathrm{mmol} / \mathrm{l}$. Glycosuria of $520(330) \mathrm{mmol} /$ day was found. Mean blood $\mathrm{pH}$ was $7 \cdot 12(0 \cdot 10)$ with a base excess of $-21.8(5 \cdot 2) \mathrm{mmol} / \mathrm{l}$.

(ii) Thirteen well controlled diabetic children who had a $\mathrm{HbA}_{1 \mathrm{c}}$ of less than $9 \cdot 5 \%$. Their age was $10 \cdot 3$ (3.0) years, and the mean duration of diabetes in this group was $2.4(2.7)$ years.

(iii) Eighteen healthy children aged 12.0 (3.4) years, who served as controls.

In 13 poorly controlled diabetics renal tubular electrolyte transport was tested during water loading. Their age was $12.7(2.25)$ years, and the mean duration of diabetes in this group was $4.3(3.4)$ years. These children had a $\mathrm{HbA}_{1 \mathrm{c}}$ of $12 \cdot 5(2 \cdot 7) \%$. Seven of 13 were just recovering from ketoacidosis. Water loading was also performed in 11 healthy children.

\section{Methods}

Urinary beta ${ }_{2}$ microglobulin concentrations. These values were determined by ELISA. ${ }^{2}$

Urinary enzyme excretion. The following three enzymes were measured.

(i) Gamma glutamyltransferase ( $\gamma$-GT EC. 2.3.2.2.) activity in the urine was determined by the MERCK 14302 test following the method of Szász. ${ }^{3}$

(ii) The assay of leucine aminopeptidase (LAP EC. 3.4.1.1.) was performed according to the method of Nagel by a Boehringer 204-323 test. ${ }^{4}$

(iii) The activity of $\mathrm{N}$-acetyl- $\beta$-D-glucosaminidase (NAG EC. 3.2.1.30.) in the urine was determined by, the method of Maruhn. ${ }^{5}$

A 24 hour urine specimen was collected in most cases, but during diabetic ketoacidosis the collection period was four hours. Mean and 2 SDs were calculated on logged data.

Investigations of renal tubular electrolyte transport. Water loading was performed according to standard methods. ${ }^{6}$ Calculations for proximal and distal electrolyte clearances were carried out according to Haycock et al. ${ }^{7}$

Creatinine. Creatinine concentration was determined by enzymatic creatinine test (Boehringer). ${ }^{8}$

Statistical analysis. For statistical evaluation, the paired Student's $t$ test was used. 


\section{Results}

Beta $_{2}$ microglobulin excretion. Excretion in 13 well controlled diabetics was similar to that of controls, but it was raised significantly during ketoacidosis compared with values pertaining in well controlled diabetics. Results are shown in Table 1. Excretion 8 to 10 days after ketoacidosis did not differ significantly from either the values of well controlled diabetics or from those of the healthy controls.

Urinary enzyme excretion. Gamma glutamyltransferase activity did not differ significantly in well controlled diabetics and healthy controls, but excretion rose significantly during ketoacidosis. The urinary leucine aminopeptidase and $\mathrm{N}$-acetyl- $\beta$-Dglucosaminidase activities in well controlled diabetics were significantly higher than those in healthy controls. In ketoacidosis further increase in the urinary activity of these enzymes occurred. Data are summarised in Table 1. Eight to 10 days later the urinary excretion of all three enzymes decreased, but the difference was not statistically significant.

Renal function and tubular electrolyte handling. There was no statistical difference in endogenous creatinine clearance during water diuresis in diabetic and control children. Free water clearance and fractional water and sodium excretion were significantly increased in diabetics. Sodium reabsorption was decreased in the proximal tubule, but it was enhanced at the distal part of the nephron: the overall effect was of increased sodium loss. The tubular phosphate reabsorption was significantly lower in diabetic than in the control children. Data are given in Table 2 and calculations in Table 3.

Table 3 Calculations

\begin{tabular}{|c|c|c|}
\hline $\begin{array}{l}\mathrm{C}_{\mathrm{Cr}} \\
\mathrm{C}_{\mathrm{H}_{2} \mathrm{O}} \\
\mathrm{Fe}_{2} \mathrm{H}_{2} \mathrm{O} \\
\mathrm{Fe}_{\mathrm{Na}_{2} \%} \% \\
\mathrm{FPR}_{\mathrm{Na}} \% \\
\mathrm{FDR}_{\mathrm{Na}} \%\end{array}$ & $\begin{array}{l}=\mathrm{U}_{\mathrm{cr}} \times \mathrm{V} / \mathrm{P}_{\mathrm{cr}} \\
=\mathrm{V}-\mathrm{C}_{\mathrm{osm}} \\
=\mathrm{V} / \mathrm{C}_{\mathrm{cr}} \times 100 \\
=\mathrm{E}_{\mathrm{Na}_{\mathrm{a}}} / \mathrm{F}_{\mathrm{Na}} \times 100 \\
=\mathrm{PR}_{\mathrm{Na}} / \mathrm{F}_{\mathrm{Na}} \times 100 \\
=\mathrm{DR} \mathrm{N}_{\mathrm{Na}} / \mathrm{F}_{\mathrm{Na}} \times 100\end{array}$ & $\begin{array}{l}\mathrm{DD}_{\mathrm{Na}}=\mathrm{P}_{\mathrm{Na}} \times\left(\mathrm{C}_{\mathrm{Na}_{\mathrm{a}}}+\mathrm{C}_{\mathrm{H}_{2} \mathrm{O}}\right) \\
\mathrm{PR}_{\mathrm{Na}}=\mathrm{F}_{\mathrm{Na}}-\mathrm{DD}_{\mathrm{Na}} \\
\mathrm{DR}_{\mathrm{Na}}=\mathrm{DD}_{\mathrm{Na}-\mathrm{E}_{\mathrm{Na}}} \\
\operatorname{TPR} \%=1-\frac{\mathrm{U}_{\mathrm{p}} \times \mathrm{P}_{\mathrm{cr}}}{\mathrm{P}_{\mathrm{p}} \times \mathrm{U}_{\mathrm{cr}}}\end{array}$ \\
\hline
\end{tabular}

$\mathrm{U}=$ urinary concentration, $\mathrm{P}=$ plasma concentration, $\mathrm{C}=$ clearance concentration, $\mathrm{cr}=$ creatinine, $\mathrm{Na}=$ sodium, osm $=$ osmolality, $\mathrm{V}=$ urine flow rate $F_{\mathrm{Na}}=$ sodium filtration rate, $\mathrm{E}_{\mathrm{Na}_{\mathrm{a}}}=$ sodium excretion rate, $D D_{\mathrm{Na}_{\mathrm{a}}}=$ rate of delivery of sodium to the distal nephron, $\mathrm{DR}_{\mathrm{Na}}=$ distal tubular sodium reabsorption rate, $\mathrm{PR}_{\mathrm{Na}}=$ proximal tubular sodium reabsorption rate. The F-prefix indicates 'fractional'-that is the proportion of the filtered load reabsorbed or excreted, $T P R=$ tubular phosphate reabsorption.

Table 1 Urinary $\beta_{2}$ microglobulin $\left(\beta_{2} M\right)$, gamma glutamyltransferase $(\gamma-G T)$, leucine aminopeptidase (LAP), $N$-acetyl- $\beta$-D-glucosaminidase (NAG) excretion in the different patient groups (values, mean (range) calculated on logged data)

\begin{tabular}{|c|c|c|c|c|}
\hline Groups & $\begin{array}{l}\beta_{2} M \\
\left(\mu g / \min \text { per } m^{2}\right)\end{array}$ & $\gamma-G T$ & $\begin{array}{c}L A P \\
(\mu \mathrm{g} / \mathrm{mmol} \text { creatinine })\end{array}$ & $N A G$ \\
\hline $\begin{array}{l}\text { Controls } \\
\qquad(n=18)\end{array}$ & $\begin{array}{l}0 \cdot 08 \\
(0 \cdot 05-0 \cdot 12)\end{array}$ & $\begin{array}{l}2 \cdot 72 \\
(1 \cdot 46-5 \cdot 01)\end{array}$ & $\begin{array}{l}0 \cdot 14 \\
(0 \cdot 11-0 \cdot 19)\end{array}$ & $\begin{array}{l}0.26 \\
(0 \cdot 18-0.39)\end{array}$ \\
\hline $\begin{array}{l}\text { Well controlled } \\
\text { diabetics } \\
(n=13)\end{array}$ & $\begin{array}{l}0 \cdot 09 \\
(0 \cdot 05-0 \cdot 15)\end{array}$ & $\begin{array}{l}3 \cdot 31 \\
(1 \cdot 62-6 \cdot 76)\end{array}$ & $\begin{array}{l}0 \cdot 19 \ddagger \\
(0 \cdot 14-0 \cdot 27)\end{array}$ & $\begin{array}{l}1 \cdot 11 \dagger \\
(0 \cdot 73-1 \cdot 50)\end{array}$ \\
\hline $\begin{array}{l}\text { Diabetics in } \\
\text { coma } \\
(n=11)\end{array}$ & $\begin{array}{l}3 \cdot 89^{*} \\
(1 \cdot 70-8 \cdot 90)\end{array}$ & $\begin{array}{l}9 \cdot 68^{*} \\
(4 \cdot 85-19 \cdot 3)\end{array}$ & $\begin{array}{l}0.32 \dagger \\
(0 \cdot 21 \dashv() \cdot 48)\end{array}$ & $\begin{array}{l}2 \cdot 57^{*} \\
\left(1 \cdot 48^{-4 \cdot 47)}\right.\end{array}$ \\
\hline $\begin{array}{l}\text { Diabetics } \\
\text { after coma } \\
(n=11)\end{array}$ & $\begin{array}{l}0 \cdot 10^{*} \\
(0 \cdot 05-0 \cdot 21)\end{array}$ & $\begin{array}{l}5 \cdot 75 \\
(2 \cdot 29-14 \cdot 40)\end{array}$ & $\begin{array}{l}0 \cdot 28 \\
(0 \cdot 18-0 \cdot 44)\end{array}$ & $\begin{array}{l}2 \cdot 19 \\
(1 \cdot 23-3 \cdot 89)\end{array}$ \\
\hline
\end{tabular}

${ }^{*} \mathrm{P}<0 \cdot 001 ;+\mathrm{P}<0 \cdot 01 ;$ and $\ddagger \mathrm{P}<0 \cdot 02$.

Table 2 Tubular electrolyte handling in poorly controlled diabetics (values mean (SD))

\begin{tabular}{|c|c|c|c|c|c|c|c|}
\hline Group & $\begin{array}{l}\text { Creatine } \\
\text { clearance } \\
\text { (mllmin per } \\
\left.1.73 \mathrm{~m}^{2}\right)\end{array}$ & $\begin{array}{l}\text { Water } \\
\text { clearance }\end{array}$ & $\begin{array}{l}\text { Fractional } \\
\text { water } \\
\text { excretion }(\%)\end{array}$ & $\begin{array}{l}\text { Fractional } \\
\text { sodium } \\
\text { excretion (\%) }\end{array}$ & $\begin{array}{l}\text { Fractional } \\
P R_{N a} \\
(\%)\end{array}$ & $\begin{array}{l}\text { Fractional } \\
D R_{\mathrm{Na}} \\
(\%)\end{array}$ & $\begin{array}{l}\text { Tubular } \\
\text { phosphate } \\
\text { reabsorption (\%) }\end{array}$ \\
\hline $\begin{array}{c}\text { Diabetics } \\
n=13\end{array}$ & $137 \cdot 4(26 \cdot 6)$ & $14 \cdot 1(5 \cdot 3)$ & $15 \cdot 7(4 \cdot 7)$ & $2.9(1.2)$ & $86 \cdot 5(4 \cdot 8)$ & $10 \cdot 5(4 \cdot 1)$ & $78.6(9 \cdot 0)$ \\
\hline $\begin{array}{c}\text { Controls } \\
n=11\end{array}$ & $132 \cdot 7(35 \cdot 1)$ & $8.9(2 \cdot 6)$ & $9 \cdot 3(2.9)$ & $0.8(0 \cdot 3)$ & $92 \cdot 1(2 \cdot 6)$ & $7 \cdot 1(2 \cdot 4)$ & $93 \cdot 7(3 \cdot 3)$ \\
\hline
\end{tabular}

$\mathrm{PR}_{\mathrm{Na}}=$ proximal tubular sodium reabsorption rate; $D R_{\mathrm{Na}}=$ distal tubular sodium reabsorption rate. 


\section{Discussion}

Tubular proteinuria is a consequence of tubular impairment. In our earlier study we found reversible tubular proteinuria in diabetic ketoacidosis even when this was of recent onset. ${ }^{1}$ We therefore investigated other parameters of tubular function in diabetic ketoacidosis.

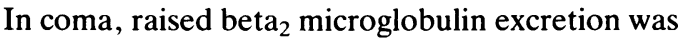
found, but this resolved 8 to 12 days after ketoacidosis. Parving et al ${ }^{9}$ also found higher excretion of this in poorly controlled diabetics.

In diabetic ketoacidosis we observed raised $\gamma$ glutamyltransferase leucine aminopeptidase, and $\mathrm{N}$-acetyl- $\beta$-D-glucosaminidase excretion. These high molecular weight enzymes originate from the tubules and are not products of glomerular filtration. Gamma glutamyltransferase is a glycoproteintype enzyme, localised in the brush border of the proximal tubules and in the loop of Henle. Leucine aminopeptidase is a proteolytic enzyme, raised urinary activity was observed in tubular impairment. ${ }^{10} \mathrm{~N}$-acetyl- $\beta$-D-glucosaminidase is detectable in the lysosomal fraction of the proximal tubular cells, and increased excretion in diabetics has been reported by several authors. ${ }^{11}$ Increased excretion of these urinary enzymes during diabetic ketoacidosis indicates tubular dysfunction.

Changes in the electrolyte transport of the renal tubular system may occur from the onset of diabetes. In poorly controlled diabetics we observed increased urinary phosphate excretion, confirming earlier findings. ${ }^{12}$ In juvenile diabetics, significantly increased urinary sodium excretion was found in relation to body surface area. When related to filtered load of sodium, however, excretion has been found higher only in newly diagnosed patients. Ditzel et $\mathbf{l}^{12}$ showed increased sodium reabsorption closely related to the increased glomerular filtration rate in well controlled diabetics. In our study, a reduced proximal tubular sodium reabsorption rate was observed in children with poor glycaemic control not compensated for by the enhanced distal sodium reabsorption.

In conclusion, a reversible tubular dysfunction may be found in diabetic ketoacidosis as well as in poorly controlled diabetes. As early as 1939, McCance and Widdowson ${ }^{13}$ had suggested that tubular injury occurred in coma.

In diabetes, there are some pathological changes in the tubules. Five to six days after the onset of hyperglycaemia, Armanni-Ebstein cells occur in the distal part of the proximal convolute. ${ }^{14}$ In streptozotocin-induced diabetes hypertrophy of the kidneys may be observed. Both the glomerular and tubular masses are proportionately enlarged. ${ }^{15}$

The relation between changes in the tubular system developing in the early phase of diabetes and the pathological changes occurring later in the glomeruli, has not, as yet, been elucidated. ${ }^{16}$

\section{References}

' Miltényi M, Körner A, Dobos M, Tichy M. Reversible tubular proteinuria associated with hyperglycaemic ketoacidosis in type 1 diabetes mellitus. Int J Pediatr Nephrol 1983;4:247-50.

${ }^{2}$ Hadnagy J, Pácsa S, Pejtsik B, Csaba I. Elevated level of $\beta_{2}$ microglobulin level in toxaemic pregnancy IRCS: Med Sci; Reproduction, Obstetrics, Gynecology 1983;11:550-2.

${ }^{3}$ Szász G. $\gamma$-Glutamyl-transpeptidase aktivität im urin. Zeitschrift für Klinische Chemie und Klinische Biochemie 1970;8:1-8.

${ }^{4}$ Nagel W, Willig F, Schmidt PH. Über die aminosäurearylamidase aktivität im menschlichen serum. Klin Wochenschr 1964;42:447-9.

5 Maruhn D. Rapid colorimetric assay of galactosidase and Nacetyl- $\beta$-glucosaminidase in human urine. Clin Chim Acta 1976;73:453-61.

- Barratt TM, Chantler C. Obstructive uropathy in infants. Proceedings of the Royal Society of Medicine 1970;63:1248-50.

${ }^{7}$ Haycock GB, Al-Dahhan J, Mak RHK, Chantler C. Effect of indomethacin on clinical progress and renal function in cystinosis. Arch Dis Child 1982;57:934-9.

${ }^{8}$ Szász G, Börner U, Busch EW. Enzymatische kreatininbestimmung im serum. Vergleich mit Jaffe-methoden. J Clin Chem Clin Biochem 1979;17:683-7.

9 Parving H-H, Noer I, Deckert T, et al. The effect of metabolic regulation on microvascular permeability to small and large molecules in short term juvenile diabetics. Diabetologia 1976;12:161-6.

${ }^{10}$ Ono T, Eto K, Arakawa E. Origin of urinary enzymes hydrolysing naphtylamides of leucine and glutamic acid. Clin Chim Acta 1968;19:257-65.

1 Whiting PH, Ross IS, Borthwick LJ. N-acetyl-D-glucosaminidase levels and the onset of diabetic microangiopathy. Ann Clin Biochem 1983;20:15-9.

12 Ditzel J, Brochner-Mortensen J. Tubular reabsorption rate as related to elevated glomerular filtration in diabetic children. Diabetes 1983;2(suppl)32:28-34.

${ }^{13}$ McCance RA, Widdowson EM. Functional disorganisation of the kidney in disease. J Physiol 1939;95:36-44.

${ }^{14}$ Wehner H. Morphologie der diabetischen nephropathie. $M M W$ 1977;119:489-92.

15 Rasch R, Nørgaard JOR. Renal enlargement: comparative autoradiographic studies of ${ }^{3} \mathrm{H}$ - Thymidine uptake in diabetic and uninephrectomized rats. Diabetologia 1983;25:280-7.

${ }^{16}$ Miltényi M. Körner A, Dobos M, Kammerer L. Changes in urinary protein excretion indicating the development of diabetic nephropathy. Diabetic Nephropathy 1984;3:112-6.

Correspondence to Professor M Miltényi, First Department of Paediatrics, Semmelweis University, Bókay-u. 53. Budapest 1083, Hungary.

Received 8 May 1985 